\title{
The ethno-techno-conservation approach in the utilization of Black Fruit (Haplolobus sp.) by the Wandamen ethnic of Papua, Indonesia
}

\author{
ANTONI UNGIRWALU ${ }^{1}$, SAN AFRI AWANG ${ }^{2}$, PRIYONO SURYANTO ${ }^{2}$, AHMAD MARYUDI ${ }^{2, \bullet}$ \\ ${ }^{1}$ Faculty of Forestry, Universitas Papua. Jl. Gunung Salju, Amban, Manokwari 98314, West Papua, Indonesia \\ ${ }^{2}$ Faculty of Forestry, Universitas Gadjah Mada. Jl. Agro No. 1 Bulaksumur, Yogyakarta 55281, Indonesia. Tel.: +62-274-550541, `email: \\ ahmad_maryudi@ugm.ac.id
}

Manuscript received: 26 May 2017. Revision accepted: 25 August 2017.

\begin{abstract}
Ungirwalu A, Awang SA, Suryanto P, Maryudi A. 2017. The ethno-techno-conservation approach in the utilization of Black Fruit (Haplolobus sp.) by the Wandamen people of Papua, Indonesia. Biodiversitas 18: 1336-1343. Identities and cultures are developed by societies through interaction with their environments. In caring for and using their environment, ecological knowledge is created. Deep knowledge of sustainable utilization and conservation of forest resources exist in Papua, but this traditional wisdom is poorly reflected in scientific literature. Such knowledge includes for example the adaptive traditional management of Black Fruit trees (Haplolobus sp.) by the Wandamen people of Papua, which is the subject of the case study reported in this paper. Our research focused on developing an understanding of how local knowledge about utilization, conservation, and protection of Black Fruit was constructed over time. It employed ethnoecology as the analytical lens. The study was conducted in Teluk Wondama District, West Papua. We found that the adaptive resource management of Black Fruit by the Wandamen is based on an approach which we have called "ethnotechno-conservation". This approach is an attitude of mind by which Wandamen communities manage their Black Fruit trees to meet the dual goals of fulfilling subsistence needs and conserving the resource. This adaptive strategy has evolved over time as a response to the dynamics of the environment and exemplifies the co-evolution of culture and environment that is a defining feature of the world we all inhabit. The traditional concepts and knowledge of the Wandaman elaborate conservation values in the utilization of the Black Fruit. These adaptive concepts and knowledge are codified in their beliefs, myths, and handed-down wisdom.
\end{abstract}

Keywords: Adaptive management, Black Fruit, ethno-techno-conservation, local wisdom, Wandamen

\section{INTRODUCTION}

Societies evolve over time; their interactions with the environment shape their identities. In many instances, their interactions with the environment result in the creation of traditional ecological knowledge (Liu et al. 2010). Traditional knowledge is rarely applied as a consideration in natural resource management at the national level. However, the pressing problems of environment depletion over recent decades have increasingly encouraged researchers and policy makers to seek alternatives to the conventional approaches to management of natural resources. In fact, there is a growing belief that the intimate synergies between local people and their environments are able to contribute positively to sustainable resource management (Stevens 1997; Kellert et al. 2000; Blaikie 2006). The involvement of local people is now seen as a key strategy in natural resource management (Maryudi et al. 2012; Mistry 2009). Adaptive traditional knowledge is increasingly valued; it is seen as having a potential to complement modern conservation approaches (Liu et al. 2010).

Worldwide, there has been a growing body of literature and studies on local ecological knowledge about the natural environment (Gerhardinger et al. 2009; Himmi et al. 2014; Iskandar et al. 2016; Tamalene et al. 2016). Nonetheless, there have been debates about the difficulties of integrating locally-based knowledge along with western knowledge as represented in the disciplines of anthropology, ethnobiology, biological conservation, and so on (Ludwig 2016). The common critiques are centered on how to improve those disciplines by incorporating historical and cultural perspectives, to broaden the naturalistic focus of purely ecological methodologies (Hobbs 2009). Hence, ethnoecology has been developed as a discipline that conceives of natural resources and their utilization as a human construct, a manifestation of knowledge systems and practices created by human-beings for survival (Campbell 2009). Researchers have increasingly proposed ethnoecology as an alternative approach to natural resource management, incorporating the perspectives of local communities, and applying sociocultural, and economic analyses to the ecosystems they inhabit and construct (Martin 2010).

Ethnoecological studies of adaptive resource management emphasize localities that have distinct biophysical and sociocultural characteristics (Ens et al. 2015; Naveh 2007; Musacchio 2009). In the Indonesian Province of West Papua, there exists a wide spectrum of the forms of sustainable utilization and conservation of forest resources. However, these are not well documented in the scientific literature. The study reported in this paper sought to examine one such under-studied case of adaptive resource management in Papua as exemplified in the traditional utilization and conservation of a species of tree known as Black Fruit (Haplolobus sp.), carried out by the 
Wandamen people of Teluk Wondama District. Our research focused on the construction of local knowledge by the Wandamen of utilization, conservation, and protection of the natural resources of this Black Fruit species. It used ethnoecology as the analytical lens. The sustainable utilization of the fruit by the Wandamen communities is a manifestation of what we call "ethno-techno-conservation".

\section{MATERIALS AND METHODS}

\section{Study area}

The Wandamen are a people sharing a common ethnicity and language group who live in the coastal areas of the Doberai Peninsula - the Bird's Head (Indonesian: Kepala Burung) - of Papua; principally in Teluk Wondama District, West Papua, Indonesia (Figure 1). The study reported in this paper was conducted in this area of Teluk Wondama District, which lies between $134^{\circ} 01^{\prime} 49^{\prime \prime}$ and $134^{\circ} 57^{\prime} 51^{\prime \prime} \mathrm{E}$, and between $1^{\circ} 58^{\prime} 27^{\prime \prime}$ and $3^{\circ} 00^{\prime} 32^{\prime \prime} \mathrm{S}$. For the study, four villages in four different Sub districts were selected, i.e. Rado (Sub district of Wasior), Kaibi (Sub district of Wondiboi), Tandia (Sub district of Rasiey) and Sobey (Sub district of Teluk Duari). The villages were purposively selected, with the main consideration being the regular utilization of the Black Fruit (Haplolobus sp.) by their inhabitants.

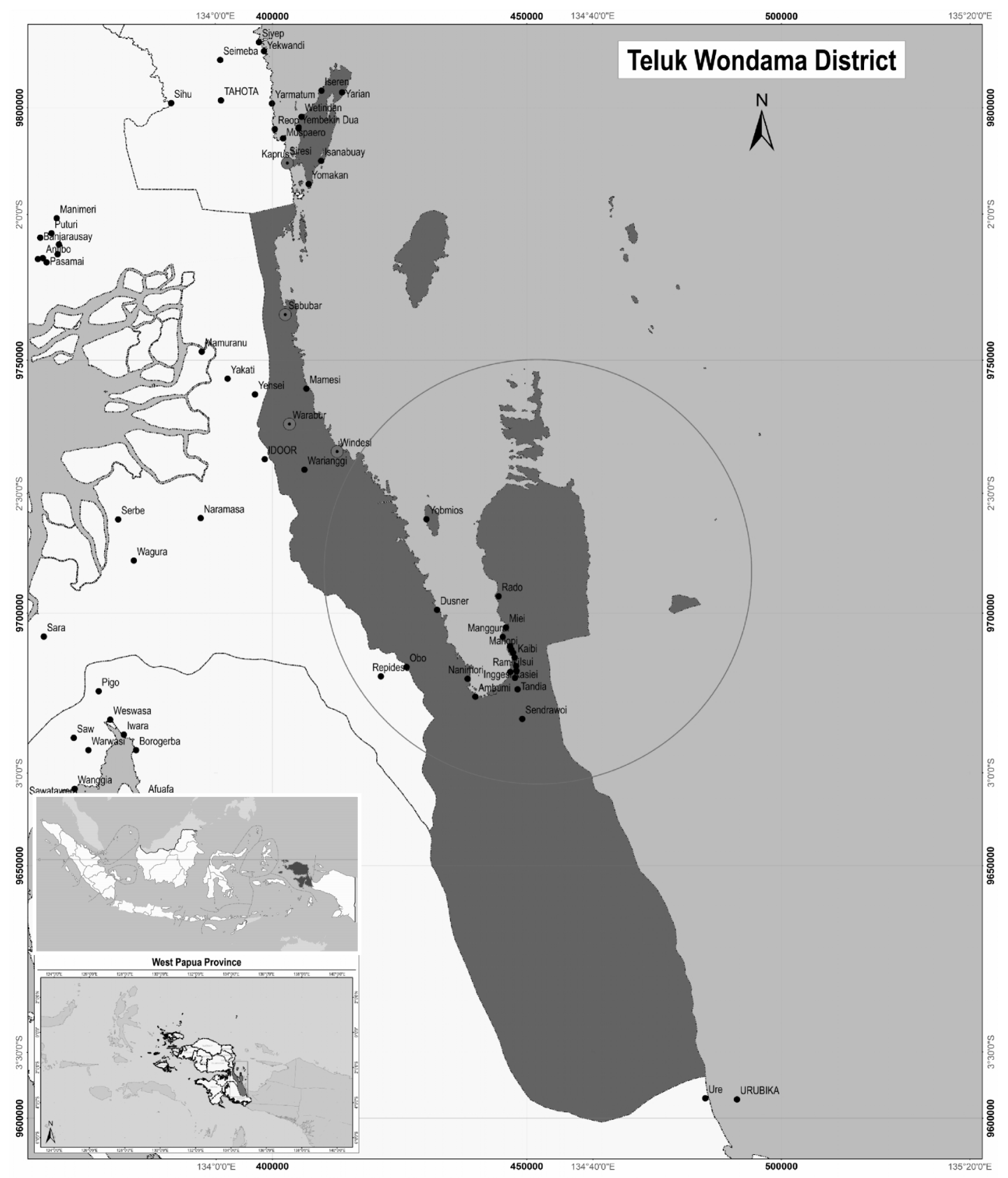

Figure 1. Location of study conducted in Teluk Wondama District, West Papua, Indonesia 


\section{Data collection}

Our study employed an ethnoecological approach, which focuses on explaining the social interactions that influence natural resource management (Spradley 2006). It focused on local knowledge systems that inform the traditional concepts in utilizing and conserving the Black Fruit resource. Data and information were collected through the following methods: review of relevant literature, direct observation, and in-depth interviews with sampled respondents and with key informants (Prabowo et al. 2016; Setiawan et al. 2016). Observation and interviews were conducted from July to December 2015. Respondents (46 people) for interviews were selected from the four studied villages. The main consideration in selecting the respondents was their active participation in Black Fruit utilization. The snowball method of sampling (Bailey 1982) was used to select the key informants (3 informants/ village) for interviews.

\section{Data analysis and interpretation}

A constructivist method was adopted in the interpretation of the data. This involves a rational, empirical, synthesis of the different perspectives of the actors (interviewees and interviewers) taking into account both the subjective perceptions of the interviewees conditioned by their local (internal) knowledge systems and of the interviewers conditioned by their more global (external) knowledge systems (Stever 1986).

Our study combined both a consideration of the natural and of the social worlds of the Wandamen communities. An ecological methodology generally objectifies nature and environment as external to the social world; somewhat independent of the society itself (Barry 1999; Awang 2006). On the other hand, social constructivist methodologies attempt to get at an understanding of the social dynamics at play in the construction and utilization of knowledge and are based on a dialectic between the main players (Berger and Luckmann 1990), and on systems theory (Parsons 1961).

According to Odum (1992), a system is an entity with interrelated and interdependent objects; bounded, but integrating both external and internal dynamics. Within a constructivist analytical framework, the external dynamics involve a process of humans reaching out into the world through physical and mental activities, while the internal dynamics involve the internalization into the human system of the objects created by these human activities (Setiadi et al. 2006).

Ethno-science, which is part of ethnography, describes the interaction between knowledge of a local community and of nature, both biotic and abiotic aspects. Therefore, we used data derived from the cognition and linguistic processes of the local classification systems and carried out a semantic analysis (Spradley 2006). The ethnographic data we gathered about the Wandamen community, and the ecological data we collected about the Black Fruit were classified and integrated (Martin 2001). Simple descriptive statistics in accordance with the methods employed by Monteiro et al. (2006) and Tamalene et al. (2016) were used to interpret the information contributed by respondents regarding the way they construct local knowledge defining pre-harvest, harvest and post-harvest stages of Black Fruit utilization.

\section{RESULTS AND DISCUSSION}

\section{Overview of Wandamen ethnic community}

The Wandamen ethnic community is characterized by property rights and tenure of natural resources based on a patrilineal system (Malinowski 1948; Mansoben 1995). The origins of their systems of property rights and leadership can be tracked through myths and beliefs that spread over considerable time within the society. Etymologically, the word "Wondama" is derived from the language of the Wamesa sub-ethnic group: "Won" meaning "a destined people"; and "Dama" meaning "a people inhabiting specific areas". The people are part of the Melanesian race, inhabiting the region along the coast of Wondama Bay, which is characterized by varying topographic conditions, ranging from flat to mountainous. There are two main tribes, i.e. Wamesa and Soug, which respectively make up $90 \%$ and $10 \%$ of the population. The people mainly speak an Austronesian language, with differing dialects spoken by sub-cultures or sub-tribes. The Summer Institute of Linguistics (2006) recognizes seven dialects of the Wandamen language, namely: Windesi, Bintuni, Wamesa, Wasior, Ambumi, Dasaner (Dusner) and Mantion. Nonetheless, our research identified 22 microethnic groupings, speaking 10 different strains/accents of the Wandamen Language (Table 1). Of the different, subethnic groupings, only the Wamesa, possesses traditional knowledge concerning conservation and utilization of the Black Fruit.

Table 1. Ecological zones, sub-ethnic groupings, and dialects, of the Wandamen people, West Papua, Indonesia

\begin{tabular}{|c|c|c|}
\hline Ecological zones & $\begin{array}{l}\text { Sub-ethnic } \\
\text { groupings }\end{array}$ & Dialects \\
\hline Coastal and estuary area & $\begin{array}{l}\text { Wamesa } \\
\text { Windesi } \\
\text { Wasior } \\
\text { Tandia } \\
\text { Werianggi } \\
\text { Werabur } \\
\text { Mamisi } \\
\text { Dusner } \\
\text { Miere } \\
\text { Ambumi } \\
\text { Kuri }\end{array}$ & $\begin{array}{l}\text { Wamesa } \\
\text { Wamesa } \\
\text { Wamesa } \\
\text { Wamesa } \\
\text { Wamesa } \\
\text { Wamesa } \\
\text { Wamesa } \\
\text { Wamesa } \\
\text { Miere } \\
\text { Waropen Kay } \\
\text { Kuri }\end{array}$ \\
\hline Coastal areas (islands) & $\begin{array}{l}\text { Rumberpon } \\
\text { Roswar } \\
\text { Roon } \\
\text { Yoop }\end{array}$ & $\begin{array}{l}\text { Wamesa } \\
\text { Roswar } \\
\text { Roon } \\
\text { Yoop }\end{array}$ \\
\hline Valley & $\begin{array}{l}\text { Mairasi } \\
\text { Sabubar } \\
\text { Ambuar } \\
\text { Iseren } \\
\text { Yarmatum } \\
\text { Wariab } \\
\text { Syari }\end{array}$ & $\begin{array}{l}\text { Mairasi/Toro } \\
\text { Soug } \\
\text { Soug } \\
\text { Soug } \\
\text { Soug } \\
\text { Soug } \\
\text { Soug }\end{array}$ \\
\hline
\end{tabular}




\section{The ecology of the Black Fruit tree}

Black Fruit (Haplolobus sp.) is a species that appears to be endemic to Melanesia, although there are members of the genus recorded in a few other parts of Malesia. It is found growing in the lowland of Papua to an altitude of about $850 \mathrm{~m}$ a.s.l. For decades, the Wandamen people have utilized Black Fruit as an alternative food source. Its extracted products can be directly consumed, or combined with sago in a prepared food known traditionally as beriam tereu. Black Fruit tree belongs to the family Burseraceae which includes the well-known canary nut trees (members of the genus Canarium L.). Black Fruit differs morphologically from the common canary (Tamalene et al. 2016). Its trunk can reach the height of $10-40 \mathrm{~m}$ with a diameter of $40-90 \mathrm{~cm}$. Its bark is dark in color and it has buttress roots. Its leaves, without stipules, are red when young, and are compound with 4-6 leaflets oppositely arranged. The flowers are small and unisexual. Male flowers have 3-6 stamens, free from each other and independent of the petals. The fruits are ovally-shaped drupes, with 1-2 smoothly coated seeds.

Black Fruit grows in three different ecological zones: (i) natural forest, (ii) secondary forest and (iii) in gardens. These three zones are defined within the traditional knowledge system concerning utilization of the plant from pre-harvest, through harvest to post-harvest (Ungirwalu et al. 2016). Primary forest is generally undisturbed, but some parts in the area have been slightly altered by human activities such as food gathering and hunting that result in changes in land cover, species utilization, and ecosystem services (Thijs et al. 2015). In the primary forest, Black Fruit is rarely a dominant species. It is sporadically scattered with an average density of about five trees per hectare. It competes for spaces with other tree species, such as Artocarpus integer (Thunb.) Merr., Lansium domesticum Corrêa, Litsea timoriana Span., Myristica fatua Houtt, Pometia acuminata Radlk., Syzygium malaccense (L.) Merr. \& L.M.Perry, Canarium sp., Intsia bijuga (Colebr.) Kuntze, and Mangifera indica L.

Secondary forest is a naturally regenerated forest following significant disturbance by human activities (Chokkalingam et al. 2000; Kanel and Shrestha 2001). The main human activity is the harvest of short-term crops for which local people carry out a slash and burn system. In the early stages, the intensification of Black Fruit utilization is done through planting a cluster of 5-8 trees per hectare. In the secondary forest, Black Fruit is found along with the following tree species: Artocarpus altilis (Parkinson ex F.A. Zorn) Fosberg, Lansium domesticum Corrêa, Artocarpus heterophyllus Lam., Mangifera indica L., Horsfieldia irya (Gaertn.) Warb., Syzygium malaccense (L.) Merr. \& L.M.Perry, Ficus septica Burm.f., Syzygium sp., Aceratium oppositifolium DC.

Tree gardening is one of the oldest farming systems in the world (Gbedoman et al. 2016). In the Wandamen garden system, Black Fruit trees are planted close to settlement and are intensively nurtured. The density of Black Fruit in the garden system is 3-7 trees per hectare, sharing spaces with the following common tree species: Lansium domesticum Corrêa, Mangifera indica L., Nephelium lappaceum L., Syzygium malaccense (L.) Merr. \& L.M. Perry, Artocarpus altilis (Parkinson ex F.A. Zorn) Fosberg, Manilkara zapota (L.) P.Royen, Artocarpus integer (Thunb.) Merr., Cerbera floribunda K.Schum., and Durio zibethinus L.
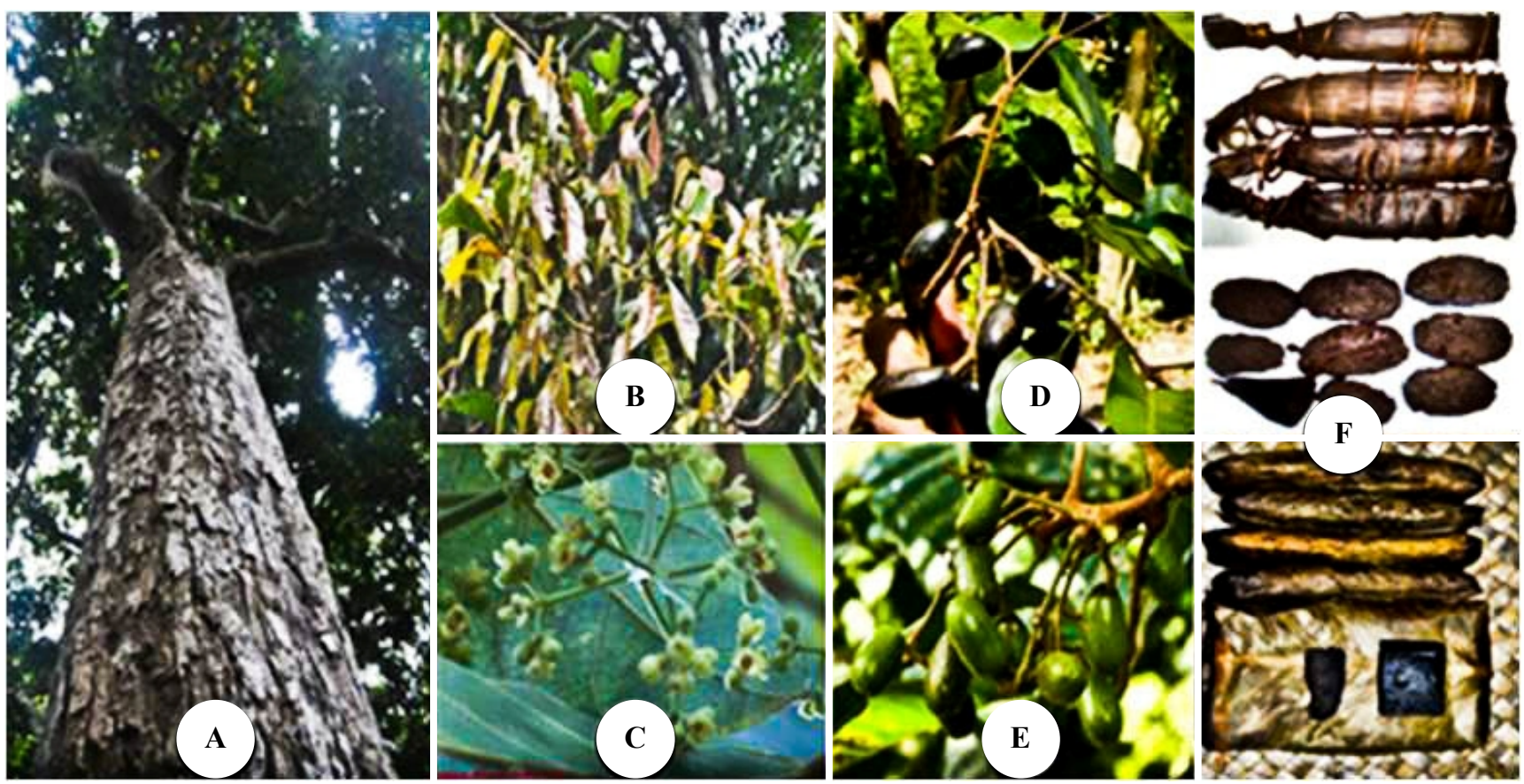

Figure 2. Morphological features of Black Fruit A. Trunk; B. Leaves; C. Flowers; D. Mature fruits; E. Unripe fruits; F. Product of Black Fruit combined with sago, beriam tereu 


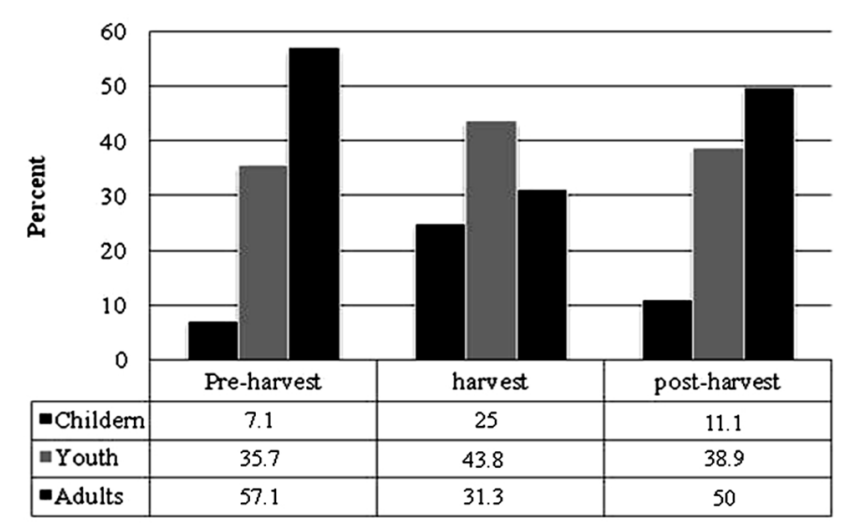

Figure 3. The proportion (\%) of each of three age groups (children, youths, and adults) involved in pre-harvest, harvest and post-harvest activities in the Wandamen utilization of Black Fruit (Haplolobus sp.)

\section{Local knowledge of Black Fruit utilization: Ethno- techno-conservation}

Local Wandamen knowledge of Black Fruit is categorized into three phases: (i) pre-harvest, which includes activities to identify species, to determine the harvest time/ seasons, and to apply pest control techniques, (ii) harvest, which includes activities to collect mature fruits based on traditional knowledge and environmentfriendly techniques, and (iii) post-harvest, which includes activities to extract the fruit and to make products such as the sago based product locally known as beriam tereu. Each stage involves division of labor based on the age groups of the people (Figure 3) and the creation of the ethno-techno-conservation approach.

Children (5-16 years of age) are rarely involved in preharvest $(7.1 \%)$ as they have less-time and are underskilled for identifying species and mature fruits, as well as in creating tools for pest control. The pre-harvest activities are generally conducted by adults (above 30 years of age) as they have accumulated the necessary knowledge for executing this crucial task (57.1\%). Youths are involved in pre-harvest activities to some extent $(35.7 \%)$. Tamalene et al. (2016) argue that adults and the older generations in general play a crucial role in the transfer of knowledge concerning traditional conservation and utilization systems. During the pre-harvest activities, there is knowledgetransfer from adults to youths so that the latter will have adequate skills in the future. The knowledge is informally obtained through youths observing how the adults execute the activities in the field. In some cases, the adults also provide an explanation to the youths.

The pre-harvest activities are parts of a systematic approach based on cognition and perception of environmental processes. Ethno-techno-conservation during pre-harvest focuses on physical observation of the forest, of the phenology of the Black Fruit, and of the conservation of targeted trees from potential pests and diseases. Fruit production generally occurs once or twice a year. The traditional tools for pest control are (i) Apiaimi and (ii)
Kabareru. Apiaimi is made of two pieces of Matoa boards (Pometia spp.) that are parallelly placed, and are bundled and hanged at one end close to the fruits. A rattan or plastic rope is attached at the other end; it is pulled from below to create noises to prevent pests (mainly bats) from eating the fruits. Kabareru is webbings of Pandanus leaves, made in the form of kites placed on the trees to create noises that prevent pests such as birds, bats and rodents. The kabareru is mounted on the tree when the fruit is ripe. When blown by the wind, this tool can create sounds used to ward off pests. This approach is locally-based, environmentfriendly, and ensures fruit production without endangering the wildlife. It ensures the ecosystem balance and achieves synergies between humans and the environment.

Figure 3 shows that harvest activities are shared by the three groups, rather equally: children (25\%), youth $(43.8 \%)$, and adults $(31.3 \%)$. This step requires efficiency and more labor. Children are intensively engaged in harvest activities, which are generally fun and require less-skills. Before the harvest, mostly women and children start with cleaning up the understory in close proximity to the targeted trees. The ritual of prayers follows, led by the clan leader. It is aimed to facilitate good harvests; there are myths that in the event of under-production inappropriate rituals must have been carried out. Kluckhohn dan Strodtbeck (1961) argue that the behavior of clan members are shaped by their leader under the patrilineal system. The culturally determined leadership system guides the direction of future generations (Mansoben 1995). The ethno-techno-conservation approach adopted during the harvest phase is reflected in the careful climbing of trees to be harvested, in which a Y-shaped pole is used to prevent destructive consequences to the environment. The method is different from the approach used by many local people in Papua who often cut branches and even fell the trees altogether simply to obtain the fruits of matoa (Pometia spp.).

As is the case in the pre-harvest phase, few children are engaged during post-harvest activities, which require specific skills and experiences. The activities are generally shared by the youths $(38.9 \%)$ and adults $(50 \%)$. The postharvest phase, i.e. the making of beriam tereu, involves complex processes. It consists of the creation of a furnace, participation in traditional ceremonies, the preparation of a traditional batter from the fruit, and the cooking process. Through the process, youths learn from the adults, who in many instances are only managing the processes. The adults are mostly tasked with the traditional ceremonies. Interaction and solidarity are part of the cultural processes, as individuals come to depend on each other and on the environment in a spirit of cooperation and mutual respect (Koentjaraningrat 2009).

The design of the furnace for the cooking prevents unnecessary waste of food, which again reflects the ethnotechno-conservation approach. Small furnaces are made to satisfy the needs of small-groups, i.e. at a household level, while the larger ones are used for special ceremonies, such as weddings, engagements, ceremonies for a new-born baby, and the election and elevation of the clan leader. It 
clearly represents the environmentally-minded wisdom of the community to conserve the local plants (Setiawan and Qiptiyah 2014, Wakhidah et al. 2017). The Wandamen people maintain a ritual approach to the processing of Black Fruit with Sago to make beriam tereu. They believe that the quality of the product symbolizes whether its production followed the correct procedures. "Good Sago" indicates that the ritual processes were in good order, and vice versa.

\section{Discussion}

This study has revealed that local people of Wandamen ethnicity construct the ethno-techno-conservation approach as an adaptive strategy in the management of their Black Fruit resource. The utilization of Black Fruit represents a unique synergy between local people and the natural resource through a traditional concept of conservation. This adaptive approach was created as a response to the dynamics of the environment. It exemplifies the coevolution of culture and the environment (de Boo and Wiersum 2002). Local knowledge was constructed through internalization, externalization, and objectification of the natural phenomena, manifested in cultural rules and myths. During this co-evolution, ethno-techno-conservation was constructed in accordance with the following processes: stimulus, encouragement, and response (Kluckhohn and
Stodbeck 1961; Koentjaraningrat 1974). The stimulus was provided by the phenomenon of Black Fruit being eaten by birds, which encouraged the people to find an explanation as to why the birds eat the fruit. It led to an understanding that the fruit is edible. The utilization of the fruit as a source for food was the response made by the people. The creation of the conservation concepts regarding the utilization of the fruit was a result of long-term processes within the development of the knowledge system. Previous generations developed logical understandings based on their cognition of nature around them, practiced this informal knowledge in their daily lives, and passed it on to the next generations.

The local knowledge of utilization and conservation of Black Fruit is codified in their beliefs, traditional rules, and culture, all expressed in their myths and shared wisdom. This wisdom is exemplified in their models for sustainable management of their natural resources (Sardjono 2004). It represents the behavior of a people responding to their environment, which reflects aspects of environmental determinism (Awang 2006). The adaptive utilization of Black Fruit by the Wandamen people takes into account conservation of the resource. The tools for utilization of the fruit, from pre-harvest to post-harvest phases, also represent adaptive technological skills, in responding to the circumstances of their environment.

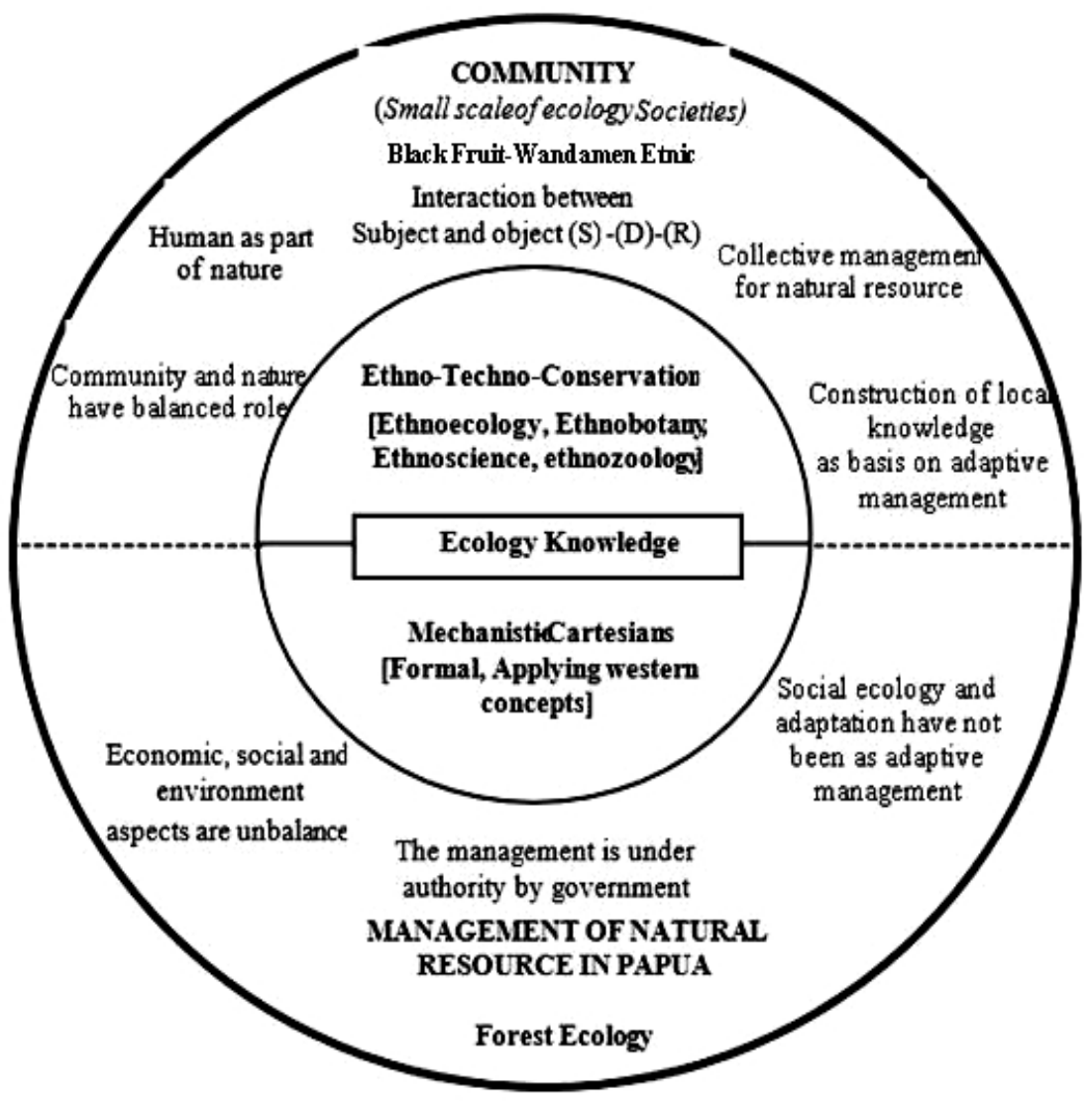

Figure 4. The connection between small-scale management of natural resources at local community level by the Wandamen people and the larger-scale management of resources in Papua as a whole 
This study also illustrates that Wandamen local knowledge, actions, and practices of natural resource management are quite distinct from the common forest management approach in Papua (Figure 4). The ethnotechno-conservation approach for the utilization of Black Fruit clearly represents an adaptive strategy to satisfy the dual goals of addressing subsistence needs and of conserving the natural resource. However, this adaptive knowledge is often neglected in larger contexts. The government provides direction on how the resource should be managed through rules, regulations, and guidelines that often differ from local practices. Large-scale forest management approaches implemented in Papua tend to follow positivist-mechanistic paradigms focusing particularly on timber extraction and tend to neglect the needs and perspectives of communities already located in the forests. Foucault (2007) states that governments establish conditions in which they implement a regime of authority to control the subjectivity of local peoples. This often leads to conflicts between the government and local peoples. It is, therefore, crucial to consider the historical and political context of local communities whose lives are so intimately connected to the environments that sustain them. Decision making over natural resources should be linked to the social and cultural aspects of these local communities and to the traditional knowledge systems by which they have conserved down the ages their natural environment and drawn sustenance from it.

\section{ACKNOWLEDGEMENTS}

This paper was initially presented at the National Seminar of Biology V in Semarang State University on 29 October 2016. We are grateful to the following people for contributing during fieldwork and in data collecting: Prof. Charlie D. Heatubun, Krisma Lekitoo, O.P. Matani, Ezrom Batorinding, and Dr. Agustinus Murdjoko. The authors also wish to thank the anonymous reviewers for providing constructive comments to improve this paper.

\section{REFERENCES}

Awang SA. 2006. Sociology Knowledge of Deforestation: Social Construction and Resistance. Debut Press, Yogyakarta. [Indonesian] Bailey KD. 1982. Methods of Social Research. Macmillan, New York Barry J. 1999. Environment and Social Theory. Routledge, New York. Berger PL, Luckmann T. 1999. Social Commentary on Reality: A Review on Sociology of Knowledge. LP3ES, Jakarta. [Indonesian]

Côrtes LHO, Zappes CA, Di Beneditto APM. 2014. Ethnoecology, gathering techniques and traditional management of the crab Ucides cordatus Linnaeus, 1763 in a mangrove forest in south-eastern Brazil. Ocean Coast Manag 93: 129-138.

de Boo H.L, Wiersum KF. 2002. Adaptive Management of Forest Resources: Principles and Process (Forest and Nature Conservation Policy Group Discussion Paper 2002-04). Wageningen University, Wageningen, The Netherlands.

Ens EJ, Pert P, Clarke PA, Budden M, Clubb L, Doran B, Douras C, Gaikwad J, Gott B, Leonard S, Locke J, Packer J, Turpin G, Wason S. 2015. Indigenous biocultural knowledge in ecosystem science and management: Review and insight from Australia. Biol Conserv 181: 133-149.
Foucault M. 2007. In: Senellart M (trans.), Burchell G. (eds.). Security, Territory, Population: Lectures at the College De France 1977-1978. Palgrave Macmillan, Basingstoke.

Gbedomon CR, Assogbadjo AE, Salako VK, Fandohan AB, Kakai RG. 2016. Exploring the spatial configurations of home gardens in Benin. Scientia Horticulturae 213: 13-23.

Gerhardinger LC, Godoy EAS, Jones PJS. 2009. Local ecological knowledge and the management of marine protected areas in Brazil. Ocean Coast Manag 52 (3-4): 154-165.

Himmi SK, Humaedi MA, Astutik S. 2014. Ethnobiological study of the plants used in the healing practices of an indigenous people Tau Taa Wana in Central Sulawesi, Indonesia. Procedia Environ Sci 20: 841846.

Hobbs R. 2009. Woodland restoration in Scotland: Ecology, history, culture, economics, politics and change. J Environ Manag 90: 28572865 .

Iskandar J, Iskandar BS, Partasasmita R. 2016. The local knowledge of the rural people on species, role and hunting of birds: Case study in Karangwangi Village, West Java, Indonesia. Biodiversitas 17 (2): 435-446.

Kanel KR, Shrestha K. 2001. Tropical secondary forests in Nepal and their importance to local people. J Trop For Sci 13 (4): 691-704.

Kellert SR, Mehta JN, Ebbin SA, Lichtenfeld LL. 2000. Community natural resource management: promise, rhetoric, and reality. Soc Nat Resour 13 (8): 705-715.

Kluckhohn FR, Strodtbeck FL. 1961.Variations in Value Orientations. Harper and Row, New York.

Koentjaraningrat RM. 1974. Culture of Mentality and Development. PT. Gramedia, Jakarta. [Indonesian]

Koentjaraningrat RM. 2009. Introduction to Anthropology (Revised Edition). Rineka Cipta, Jakarta. [Indonesian]

Liu J, Ouyang Z, Miao H. 2010. Environmental attitudes of stakeholders and their perceptions regarding protected area-community conflicts : A case study in China. J Environ Manag 91 (11): 2254-2262.

Ludwig D. 2016. Overlapping ontologies and Indigenous knowledge. From integration to ontological self-determination. Stud Hist Philos Sci 59: 36-45.

Malinowski B. 1948. Culture. Encyclopedia of the Social Science 4: 621645.

Mansoben JR. 1995. Traditional Political System in Irian Jaya. Series 5. Indonesian Institute of Sciences (LIPI) and Leiden University (RUL), Jakarta. [Indonesian]

Martin GJ. 2010. Ethnobiology and Ethnoecology. Encyclopedia of Biodiversity. 2nd ed. Academic Press, New York.

Maryudi A, Devkotab RR, Schusser C, Yufanyi C, Salla M, Aurenhammer H, Rotchanaphatharawitb R, Krot M. 2012. Back to basics: Considerations in evaluating the outcomes of community forestry. For Pol Econ 14: 1-5.

Mistry J. 2009. Indigenous Knowledge. International Encyclopedia of Human Geography. 371-376

Musacchio LR. 2009. The ecology and culture of landscape sustainability: emerging knowledge and innovation in landscape research and practice. Landscape Ecol 24: 989-992.

Naveh Z. 2007. Landscape ecology and sustainability. Landscape Ecol 22: 1437-1440.

Odum HT. 1992. System Ecology: An Introduction. Gadjah Mada University Press, Yogyakarta. [Indonesian]

Paijmans K. 1970. An analysis of four tropical rain forest sites in New Guinea. J Ecol 58 (1): 77-101.

Parsons T (ed). 1961. Theory of Society. The Free Press, New York.

Prabowo D, Maryudi A, Senawi, Imron MA. 2017. Conversion of forests into oil palm plantations in West Kalimantan, Indonesia: Insights from actors' power and its dynamics. For Pol Econ 78: 32-39.

Sardjono, Mustofa A. 2004. Sociology of Forestry Mosaic: Local Communities, Politics and Sustainability of Resources. Debut Press, Yogyakarta. [Indonesian]

Setiadi EM, Hakam KA, Effendi R. 2006. Principles of Social and Cultural Sciences. 2nd ed. Kencana, Jakarta. [Indonesian]

Setiawan H, Qiptiyah M. 2014. The ethnobotany study of Moronene indigenous tribes at Rawa Aopa Watumohai National Park. Jurnal Penelitian Kehutanan Wallacea 3 (2): 107-117

Setiawan EN, Maryudi A, Purwanto RH, Lele G. 2016. Opposing interests in the legalization of non-procedural forest conversion to oil palm in Central Kalimantan, Indonesia. Land Use Pol 58: 472-481. 
Spradley J.. 2006. Ethnographic Methods. 2nd ed. Tiara Wacana, Yogyakarta. [Indonesian]

Stevens S. 1997. Conservation Through Cultural Survival. Island Press, Washington, D.C.

Tamalene MN, Al Muhdhar MHI, Suarsini E, Rahman F, and Hasan S. 2016. Ethnobotany of Canarium plant species used by Tobelo Dalam (Togutil ) ethnic community of Halmahera Island, Indonesia. Biodiversitas 17 (1): 61-69

Thijs KW, Aertsa R, van de Moortelec P, Aben J, Musilae W, Pellikkaf P, Gulinck H, Muys B. 2015. Trees in a human-modified tropical landscape: Species and trait composition and potential ecosystem services. Landsc Urb Plann 144: 49-58.

Ungirwalu A, Awang SA, Suryanto P, Maryudi A. 2016. Adaptive management of Black Fruit (Haplolobus monticola) by Ethnic Wandamen, Papua. Jurnal Manusia dan Lingkungan 23 (2): 266-275. [Indonesian]

Wakhidah AZ, Silalahi M, Pradana DH. 2017. Inventory and conservation plant of oke sou traditional ceremony; A welcoming tradition of maturity girl on the community of Lako Akediri Village, West Halmahera, Indonesia. Biodiversitas 18 (1): 65-72. 